\title{
Convective Drying of Osmo-Treated Abalone (Haliotis rufescens) Slices: Diffusion, Modeling, and Quality Features
}

\author{
Roberto Lemus-Mondaca ${ }^{(1)},{ }^{1}$ Sebastian Pizarro-Oteíza, ${ }^{2}$ \\ Mario Perez-Won, ${ }^{2}$ and Gipsy Tabilo-Munizaga ${ }^{3}$ \\ ${ }^{1}$ Departamento de Ciencia de los Alimentos y Tecnología Química, Facultad de Ciencias Químicas y Farmacéuticas, \\ Universidad de Chile, Santos Dumont 964, Independencia, Santiago, Chile \\ ${ }^{2}$ Departamento de Ingeniería en Alimentos, Universidad de La Serena, Av. Raúl Bitrán 1305, La Serena, Chile \\ ${ }^{3}$ Departamento de Ingeniería en Alimentos, Universidad del Bío-Bío, Av. Andrés Bello 720, Chillán, Chile
}

Correspondence should be addressed to Roberto Lemus-Mondaca; roberto.lemus@ciq.uchile.cl

Received 17 October 2017; Revised 6 January 2018; Accepted 14 February 2018; Published 24 April 2018

Academic Editor: Alex Martynenko

Copyright (C) 2018 Roberto Lemus-Mondaca et al. This is an open access article distributed under the Creative Commons Attribution License, which permits unrestricted use, distribution, and reproduction in any medium, provided the original work is properly cited.

\begin{abstract}
The focus of this research was based on the application of an osmotic pretreatment $(15 \% \mathrm{NaCl})$ for drying abalone slices, and it evaluates the influence of hot-air drying temperature $\left(40-80^{\circ} \mathrm{C}\right)$ on the product quality. In addition, the mass transfer kinetics of salt and water was also studied. The optimal time of the osmotic treatment was established until reaching a pseudo equilibrium state of the water and salt content $(290 \mathrm{~min})$. The water effective diffusivity values during drying ranged from 3.76 to $4.75 \times 10^{-9} \mathrm{~m}^{2} / \mathrm{s}$ for three selected temperatures $\left(40,60\right.$, and $\left.80^{\circ} \mathrm{C}\right)$. In addition, experimental data were fitted by Weibull distribution model. The modified Weibull model provided good fitting of experimental data according to applied statistical tests. Regarding the evaluated quality parameters, the color of the surface showed a change more significant at high temperature $\left(80^{\circ} \mathrm{C}\right)$, whereas the nonenzymatic browning and texture showed a decrease during drying process mainly due to changes in protein matrix and rehydration rates, respectively. In particular, working at $60^{\circ} \mathrm{C}$ resulted in dried samples with the highest quality parameters.
\end{abstract}

\section{Introduction}

The red abalone (Haliotis rufensces) is an herbivorous gastropod mollusk living naturally in the bedrock of water between 1 and $30 \mathrm{~m}$ depth. The culture of abalone has increased considerably, since it is highly appreciated as a seafood of high commercial value, especially in countries like China and Japan [1], enjoying the firm texture, as well as cooked product tenderness [2]. This species of abalone is considered exotic seafood and is one of the most expensive seafood products (Briones-Labarca et al., 2011). From the above, the Aquaculture in Chile has grown considerably, while exports have been important after copper, forestry, and fruits, considering that for the future it will be one of the most important sources of food for the world. This way, the cultivation has been currently focused on univalve (red abalone), bivalves (oysters), crustaceans (lobsters), cephalopods (cuttlefish), and salmon species, all with growing demand around the world [3].

Marine products are extremely perishable and the time to spoilage depends mainly on species, handling, processing, and storage temperature [4]. Currently, these products are sold as frozen, canned, or cooked frozen. However, the procedures involved can affect the quality attributes such as texture and taste [5]. Therefore, new treatments and/or processes are needed to minimize biological reactions and physicochemical leading to the loss of food quality [5] in order to increase product shelf-life.

Many studies have focused on different methods of preservation, with the hot-air drying being one of the most important processes $[6,7]$. This process reduces the water activity through loss of moisture, preventing the growth and reproduction of microorganisms [8]. Convective drying 
is one of the most used industrial methods for drying food and biological materials, in order to preserve its quality and stability, so avoiding spoilage and contamination during the storage period $[1,9,10]$. However, it is known that the drying process causes the loss of function of the cell membranes especially when the temperature increases causing significant changes in sensory and nutritional food quality. These disadvantages can be reduced using a combination of different pretreatments. From these pretreatments, the most widely used in convective drying are osmotic dehydration, blanching, microwave drying, and enzyme solution, among others. [11]. Commonly, marine products are immersed in concentrated solutions to impregnate them with salt and/or other curing ingredients (sucrose, glucose, fructose, glycerol, sorbitol, and sodium chloride) to prolong shelf-life $[5,12]$. The osmotic pretreatment scarcely affects the color, flavor, and texture of these products. It diminishes also the loss of nourishing substances and does not have a high exigency of energy due to the used temperatures, generally that of the environment.

Knowledge of the drying kinetics is used not only in the evaluation process, but rather to analyze and predict the drying process variables to minimize damage to final product and optimize drying time and excessive energy consumption $[1,9,13]$. This analysis can be performed with different mathematical models such as Newton, Henderson-Pabis, Page, Modified Page, Weibull, Two-Term, Midilli-Kucuk, and Logarithmic models $[14,15]$. Nonetheless, in the literature, there is no information available about the use of Weibull distribution model for the marine product dehydration [16]. The Weibull model has been used to describe, among others, the kinetics: high pressure removal of Bacillus subtilis [17], rehydration of breakfast cereals [18], loss of water during osmotic dehydration of food [19], and heat resistance of Bacillus cereus [20].

Thus, the aim of this research was to study the influence of drying temperature on the mass transfer kinetics of osmotically pretreated abalone slices and to evaluate different quality characteristics such as color, rehydration capacity, texture profile (TPA), no enzymatic browning (NEB), total volatile basic nitrogen (TVBN), and antioxidant capacity of the dried-rehydrated product.

\section{Materials and Methods}

2.1. Samples Preparation and Osmotic Pretreatment. The red abalone (Haliotis rufescens) samples were collected from an aquaculture Company (Live Seafood Chile SA, Coquimbo, Chile). These samples with a weight of $20.0 \pm 0.2 \mathrm{~g}$ were delivered alive from the company to the university laboratory. Then, they were slaughtered, shucked, cleaned, and washed with fresh water until the blue pigment haemocyanin was removed. Finally, the samples were cut into slices of $10 \mathrm{~mm}$ long $\times 0.1 \mathrm{~mm}$ wide $\times 0.1$ thick to consider one dimension and were immersed in a salt solution $(\mathrm{NaCl}, 15 \mathrm{~g} / 100 \mathrm{~mL})$ at $20^{\circ} \mathrm{C}$ as proposed by Lemus-Mondaca et al. [13] in the red abalone (Haliotis rufescens) and Boudhrioua et al. [21] in sardine fillets. The brine to sample ratio was maintained at $8: 1$ in order to not dilute the osmotic solution by water removal during experiments. The brine was agitated continuously in a water bath (Quimis, Q.215.2, Sao Paulo, Brazil) to maintain a uniform temperature. The osmotic process was made up of regular time intervals $(0,15,30,45,60,120,180,240,300$, 360 , and $420 \mathrm{~min}$ ) until reaching an osmotic pseudo equilibrium. Moisture content was determined by AOAC method $\mathrm{n}^{\circ} 934.06$ (AOAC, 1990) using an analytic balance (Chyo, Jex120, Kyoto, Japan) with a $\pm 0.0001 \mathrm{~g}$ accuracy and vacuum drying oven (Gallenkamp, OVA031, Leicester, UK). As to salt content, this one was measured by Mohr method [22], where salt content was expressed as $\mathrm{g} \mathrm{NaCl} / 100 \mathrm{~g}$ sample. All the experimental determination was performed in triplicate.

2.2. Drying Procedure. Once the osmotic balance of the salt and water content has been reached, convective drying was carried out. The convective drying process was performed in a convective dryer tray designed and fabricated by the Department of Food Engineering at the University of La Serena, Chile [7]. Drying temperatures were 40,60 , and $80^{\circ} \mathrm{C}$ at a constant air velocity $1.5 \pm 0.2 \mathrm{~m} / \mathrm{s}$ for each test with an environmental condition of $18.0 \pm 0.1^{\circ} \mathrm{C}$ and $68.1 \pm 3.8 \% \mathrm{RH}$, the latter being measured by a digital hygrothermometer (Extech Instrument Inc., 451112, Waltham, MA, USA). The experiments ended when a state of pseudo equilibrium was reached at a constant weight between $22-18 \%$ humidity and $0.73-0.62$ water activity according to the temperatures evaluated. The samples were sealed in polyethylene bags and each experiment was made in triplicate. The samples were sealed in polyethylene bags and each experiment was made in triplicate.

2.3. Diffusion Coefficient. In order to study the phenomena of mass transfer during osmotic dehydration and convective drying process of abalone samples, two components were considered in each process: (a) the water loss and salt gain for OD and (b) the water loss for convective drying. Fick's second law has been widely used to describe the dynamics of the different drying processes for biological materials [23]. The mathematical solution of Fick's second law was used to describe the period, when internal mass transfer (water or salt) is the controlling mechanism and one-dimensional transport in an infinite slab [24], shown in (1), which corresponds to the geometry of a semi-infinite slab. Thus, the variables of diffusion model are moisture loss (MR) (see (2)) and salt gain rate (SR) (see (3)) [25], represented as follows:

$$
\text { MR_or_SR }=\sum_{i=0}^{\infty} \frac{8}{(2 i+1) \pi^{2}} \exp \left(\frac{D_{e}(2 i+1) \pi^{2} t}{4 L^{2}}\right) .
$$

For sufficiently long drying times, the first term $(i=0)$ in the series expansion of (1) gives a good estimation of the solution and can be applied to determine the water and salt diffusion coefficients, (2) and (3), respectively [25]. Then, Fick's 2nd law (see (1)) can be linearized, from the slope $\left(=\pi^{2} D_{e} / 4 L^{2}\right)$, where $D_{w e}$ and $D_{s e}$ are moisture loss or salt gain, respectively, that can be obtained. 


$$
\begin{aligned}
\mathrm{MR} & =\frac{M_{t}}{M_{o}}=\frac{8}{\pi^{2}} \exp \left(\frac{D_{w e} \pi^{2} t}{4 L^{2}}\right), \\
\mathrm{SR} & =\frac{S_{t}}{S_{o}}=\frac{8}{\pi^{2}} \exp \left(\frac{D_{s e} \pi^{2} t}{4 L^{2}}\right) .
\end{aligned}
$$

The influence of drying temperature was determined according to the Arrhenius type equation (4), where kinetic parameters $\left(E_{a}\right.$ and $\left.D_{o}\right)$ of this model can be estimated from the slope and intercept of the plot in $D_{e}$ versus the reciprocal of absolute temperature $[10,23]$ :

$$
D_{e}=D_{o} \exp \left(\frac{-E_{a}}{R T}\right)
$$

2.4. Mathematical Modeling. Commonly, the authors propose some simple and complex mathematical models to simulate drying curves of foods that can provide an adequate representation of the experimental results [26]. Several models exist in the literature to predict this process [27]. Among these models, the Weibull distribution model has been used to describe diverse cases, for example, the removal of Bacillus subtilis for a high pressure treatment (Knorr, 1996), rehydration of breakfast cereals [18], and pressure inactivation of bacteria [28]. The mathematical expression was based on the diffusional mechanism of water, expressed in

$$
\mathrm{MR}_{\mathrm{or}_{\mathrm{SR}}}=\exp \left(-\left[\frac{t}{\beta}\right]\right)^{\alpha} .
$$

\section{Quality Characteristics}

3.1. Proximate Analysis and Water Activity $\left(a_{w}\right)$. The moisture content determination was performed according to AOAC methodology number 934.06 using an analytical balance (Chyo, Jex120, Kyoto, Japan) with an accuracy of $\pm 0.0001 \mathrm{~g}$ and a vacuum drying oven at $60^{\circ} \mathrm{C}$ (Gallenkamp, OVA031, Leicester, UK). The crude protein content was determined by the Kjeldahl method (AOAC number 920.39), applying a conversion factor of 6.25 . The fat content was determined by the Soxhlet method (AOAC number 920.39) and total ash by oxidation of the organic matter at $550^{\circ} \mathrm{C}$ (AOAC number 923.08). The methods were performed according to the AOAC (1990) methodology and all the analyses were done in triplicate. In addition, water activity $\left(a_{w}\right)$ was measured (AQUA LAB, 4TE, Pullman, WA, USA).

3.2. Nonenzymatic Browning (NEB) and Total Volatile Basic Nitrogen (TVBN). The proposed methodology for determining the NEB compounds dissolved in water rehydration was proposed by Vega-Gálvez et al. [29]. The samples were rehydrated at a ratio $(1: 10) \mathrm{g}$ sample/g water $\times 12 \mathrm{~h}$. Then, the procedure was divided into three stages. The first was a clarification of rehydration water with centrifugation at $3500 \mathrm{rpm} \times 15 \mathrm{~min}$. The second step was a dilution $(1: 1)$ of this supernatant with ethanol (Sigma Chemical Co., St. Louis, MO, USA) at $95 \%$ (pa) centrifuged again to the same conditions and finally the third was read (absorbance at $420 \mathrm{~nm}$ ) from the extracts that was determined to clear quartz in buckets using a spectrophotometer (Spectronic 20 Genesys, Illinois, USA). All measurements were done in triplicate and NEB was expressed as Abs/g d.m [29]. Total volatile basic nitrogen (TVBN) was determined on 5-16 g of chopped abalone samples using direct distillation with $\mathrm{MgO}$ with a Kjeldahl distillation apparatus and titration according to previous work [30]. All measurements were done in triplicate.

3.3. Surface Color. Total color change $(\Delta E)$ was calculated from the initial sample surface color (fresh sample) versus the surface color of the processed product (rehydrated sample) (see (6)) using a Colorimeter (HunterLab, model MiniScan ${ }^{\mathrm{TM}}$ XE Plus, Reston, VA, USA). Color was determined by CIELab method, where $L^{*}$ is whiteness or brightness, $a^{*}$ is redness/greenness, and $b^{*}$ is yellowness/blueness coordinates; standard illuminant $D_{65}$ and observer $10^{\circ}$ [29] were obtained, where $L_{o}, a_{o}$, and $b_{o}$ are the control values determined for fresh sample.

$$
\Delta E=\sqrt{\left(a^{*}{ }_{r}-a_{o}\right)^{2}+\left(b^{*}{ }_{r}-b_{o}\right)^{2}+\left(L^{*}{ }_{r}-L_{o}\right)^{2}} .
$$

3.4. Rehydration Indexes. Dry samples were rehydrated using a solid/liquid mass ratio of $1: 50$, within a time of 12 hours at room temperature. The rehydration ratio (RR) was calculated according to (7) and expressed as g absorbed water/g dry matter. The water holding capacity (WHC) of the samples rehydrated with the same above condition was centrifuged at $3500 \mathrm{~g} \times 20 \mathrm{~min}$ at $5^{\circ} \mathrm{C}$ in tubes equipped with a plastic mesh centrally placed, allowing water to drain from the sample during centrifugation. This water holding capacity expressed as retained water $/ 100 \mathrm{~g}$ water was determined according to (8) [29]. All measurements were done in triplicate.

$$
\begin{aligned}
\mathrm{RR} & =\frac{W_{r} \times X_{r}-W_{d} \times X_{d}}{W_{d}\left(1-X_{d}\right)} \times 100, \\
\mathrm{WHC} & =\frac{W_{r} \times X_{r}-W_{l}}{W_{r} \times X_{r}} \times 100 .
\end{aligned}
$$

3.5. Texture Profile Analysis (TPA). The texture profile of samples, as an indicator of chewiness, springiness, resilience, cohesiveness, and hardness, was measured using a Texture Analyzer (Texture Technologies Corp., TA XT2 Scardale, NY, USA). The probe had a puncture diameter of $2.0 \mathrm{~mm}$ that was $P / 100$ with a distance of $20 \mathrm{~mm}$ and test speed of $1.7 \mathrm{~mm} / \mathrm{s}$. The maximum force was measured by making 1 puncture in each abalone sample, using 10 slices per treatment. TPA parameters, including hardness, gumminess, chewiness elasticity, cohesiveness, and resilience, were evaluated by a typical force-time curve [2].

3.6. Antioxidant Activity. A lipid extraction was performed with the Soxhelt method (AOAC N ${ }^{\circ}$ 920.39). This extract was reconstituted with ether: ethanol $50 \% \mathrm{v} / \mathrm{v} 50 \mathrm{~mL}$ flask to react with the reagent $1,1^{\prime}$-diphenyl-2-picrylhydrazyl (DPPH), modified according to Brand-Williams et al. [31]. The solution of radical (DPPH) was prepared by dissolving $2.0 \mathrm{mg} \mathrm{DPPH}$ 
in $100 \mathrm{~mL}$ of ether-ethanol (50\%). Then, $0.1 \mathrm{~mL}$ of sample was extracted with $3.9 \mathrm{~mL}$ of the DPPH solution. Control sample was prepared without adding extract. Once the samples spiked with DPPH, it was placed in the darkness for 30 minutes and the absorbance was measured at $517 \mathrm{~nm}$, using a spectrophotometer (Spectronic 20 Genesys, Illinois, USA). Results were expressed in micromoles of Trolox equivalents TE [32]. All measurements were done in triplicate.

3.7. Statistical Analysis. The fit quality of all models was evaluated using the sum square error (SSE) (see (9)) and Chi-square $\left(\chi^{2}\right.$, see (10)) tests [33]. The effect of air-drying temperature on each quality parameter was estimated by Statgraphics Plus v.5 (Statistical Graphics Corp., Herndon, VA, USA). The results were analyzed by an Analysis of Variance (ANOVA) using a factorial design to one single factor (temperature) with 3 levels $\left(40,60\right.$, and $\left.80^{\circ} \mathrm{C}\right)$ at a confidence interval of $95 \%$ with a Multiple Range Test (MRT).

$$
\begin{aligned}
\mathrm{SSE} & =\frac{1}{N} \sum_{i=0}^{\infty}\left(\mathrm{MR} \_ \text {or_SR } \mathrm{SR}_{e i}-\mathrm{MR} \_ \text {or } \_\mathrm{SR}_{c i}\right)^{2}, \\
\chi^{2} & =\frac{\sum_{i=0}^{\infty}\left(\mathrm{MR} \_ \text {or_SR } \mathrm{SR}_{e i}-\mathrm{MR} \_ \text {or_SR } \mathrm{SR}_{c i}\right)^{2}}{N-m} .
\end{aligned}
$$

\section{Results and Discussion}

4.1. Effective Moisture and Salt Diffusivity. According to the kinetics of mass transfer of salt and water in the osmotic process (Figure 1), the optimum time was observed, based on (2) and (3). This osmotic equilibrium was between 270 and 300 minutes. These values were similar to those estimated by Telis et al. [34] in caiman fillet and Mujaffar and Sankat [35] in shark muscle. The values of the effective water and salt diffusivity in the osmotic process ((4) and (5)) were of $2.74 \times$ $10^{-10} \mathrm{~m}^{2} / \mathrm{s}$ and $7.19 \times 10^{-10} \mathrm{~m}^{2} / \mathrm{s}$, respectively. This occurs by the simultaneous movements of $\mathrm{NaCl}$ and water in the tissue, that is, the concentration differences and osmotic pressure exerted between the cell and the solution [36]. Although there is few data about this process applied to the abalone samples, a similar tendency was obtained by Corzo and Bracho [27], in the case of the sardine for value of $D_{w e}$; and in the OD of sardine fillets, Boudhrioua et al. [21] observed that the $D_{w e}$ values ranged from $2.40 \times 10^{-10}$ to $1.9 \times 10^{-8} \mathrm{~m}^{2} / \mathrm{s}$.

Concerning the effective moisture diffusivity in the drying process, the values oscillated from $3.76 \times 10^{-9}$ to $4.76 \times$ $10^{-9} \mathrm{~m}^{2} / \mathrm{s}$, according to the drying temperatures. These values agreed with those found by Panagiotou et al. [37] in seafood drying, which varied from $10^{-11}$ to $10^{-9} \mathrm{~m}^{2} / \mathrm{s}$. Ortiz et al. [38] attained similar results with the salmon drying (Salmon salar L.) at temperatures that ranged from 40 to $60^{\circ} \mathrm{C}$, with values between $1.08 \times 10^{-10}$ and $1.90 \times 10^{-10} \mathrm{~m}^{2} / \mathrm{s}$; Vega-Gálvez et al. [29] also obtained similar results in the jumbo squid drying, at temperatures from 40 to $90^{\circ} \mathrm{C}$ with values of $0.78 \times 10^{-9}$ to $3.22 \times 10^{-9} \mathrm{~m}^{2} / \mathrm{s}$, together with Medina-Vivanco et al. [39] for tilapia fillets drying. The differences among these values could be explained by the diversity of seafood species that presented changes in temperature, muscular type and position, fat content, and presence or absence of skin [39].

Arrhenius equation $\left(r^{2}>0.85\right)$ was proposed by VegaGálvez et al. [29]. The Arrhenius factor $\left(D_{0}\right)$ that attained a value of $3.17 \times 10^{-8} \mathrm{~m}^{2} / \mathrm{s}$ and the activation energy $\left(E_{a}\right)$ of $5.48 \mathrm{~kJ} / \mathrm{mol}$ were calculated in agreement with (7). Such values showed a clear dependence on the drying temperature, demonstrating that $\left(D_{w e}\right)$ values increase meaningfully as temperature increases. Furthermore, it can be concluded that abalone was more sensitive to temperature than other species according to its $E_{a}$ low-value, if it is compared to the jumbo squid [29], which attained a value of $28.93(\mathrm{~kJ} / \mathrm{mol})$, and salmon [38] that showed a value of $24.57(\mathrm{~kJ} / \mathrm{mol})$. The abalone's value was lower, due to the difference in the composition of its protein content, compared to the other seafood species mentioned before; therefore, it is concluded that, during the drying period, there would be a lower denaturalization that would not hinder the water diffusional transfer (crustening), considering that a lower $E_{a}$ value means a higher sensitivity within the evaluated temperature range $[26,40]$.

4.2. Weibull Model Applied to Osmotic Dehydration. Figure 1 shows the transfer of kinetic mass (water and salt) in a pseudo equilibrium state experimental and calculated by using the Weibull model to $15 \% \mathrm{NaCl}$, with $\chi^{2}=0.000595$, SSE $=$ 0.000463 , and $r^{2}=0.94$. The $\beta$ parameter, both for salt gain and for water loss, was $0.0093 \pm 0.0103$ to $7659 \pm 1492.2$ (min), respectively. With respect to the values of $\alpha$ parameter for salt gain and water loss, they were in a range of $0.101 \pm 0.010$ to $0.404 \pm 0.024$, respectively. Similar results were reported by Corzo and Bracho [16] regarding sardine's water loss with $\alpha$ values ranging from 0.665 to 0.469 , under similar concentrations.

4.3. Weibull Model Applied to Drying Procedure. The complexity of mass transfer process makes it difficult to obtain an accurate prediction because they depend on parameters and equilibrium conditions as well as the effective water diffusivity. Thus, the Weibull's model was used (Figure 2), which shows the drying curves of 40,60 , and $80^{\circ} \mathrm{C}$ of abalone samples pretreated osmotically and adjusted according to this model $\left(0.0002<\chi^{2}<0.00048 ; 0.00021<\right.$ SSE $<0.0004$; $\left.0.981<r^{2}<0.993\right)$. It can be seen that all curves are exponential being typical for drying food [1]. The behavior of the drying curves was also reported by other authors when they worked with lobster [29]. The drying curves 60 and $80^{\circ} \mathrm{C}$ that have a similar tendency are explained by the formation of a crust in the area of the abalone samples surface associated with osmotic pretreatment and thermal chock. This crust has a significant resistance to water migration [35]. Drying curves or drying rates depend on several factors, some of them being directly related to the product and others related to the airdrying temperature [41]. Table 1 shows the moisture diffusivity coefficient, which was the most significant parameter in the food drying [42], based on Fick's second law [23].

In particular, the values of $\alpha$ and $\beta$ Weibull parameters showed significant differences among evaluated temperatures, with a $p$ value $<0.05$. Similar results were obtained by Vega-Gálvez et al. [29] in the jumbo squid drying at the same 
TABLE 1: Kinetic parameters of Weibull and Fick models for drying process.

\begin{tabular}{lcccc}
\hline \multirow{2}{*}{ Model } & Parameter & \multicolumn{3}{c}{ Drying temperature $\left({ }^{\circ} \mathrm{C}\right)$} \\
& & 40 & 60 & 80 \\
\hline \multirow{2}{*}{ Weibull } & $\beta$ & $146.03 \pm 1.929^{\mathrm{a}}$ & $94.84 \pm 2.282^{\mathrm{b}}$ & $67.32 \pm 1.701^{\mathrm{c}}$ \\
& $\alpha$ & $0.827 \pm 0.022^{\mathrm{a}}$ & $0.733 \pm 0.014^{\mathrm{b}}$ & $0.685 \pm 0.018^{\mathrm{c}}$ \\
Fick & $D_{w e} \times 10^{-9}$ & $3.76 \pm 0.146^{\mathrm{a}}$ & $4.64 \pm 0.246^{\mathrm{b}}$ & $4.75 \pm 0.052^{\mathrm{b}}$ \\
\hline
\end{tabular}

Identical letters above the values indicate no significant difference $(p<0.05)$. Values are mean \pm standard deviation $(n=3)$.

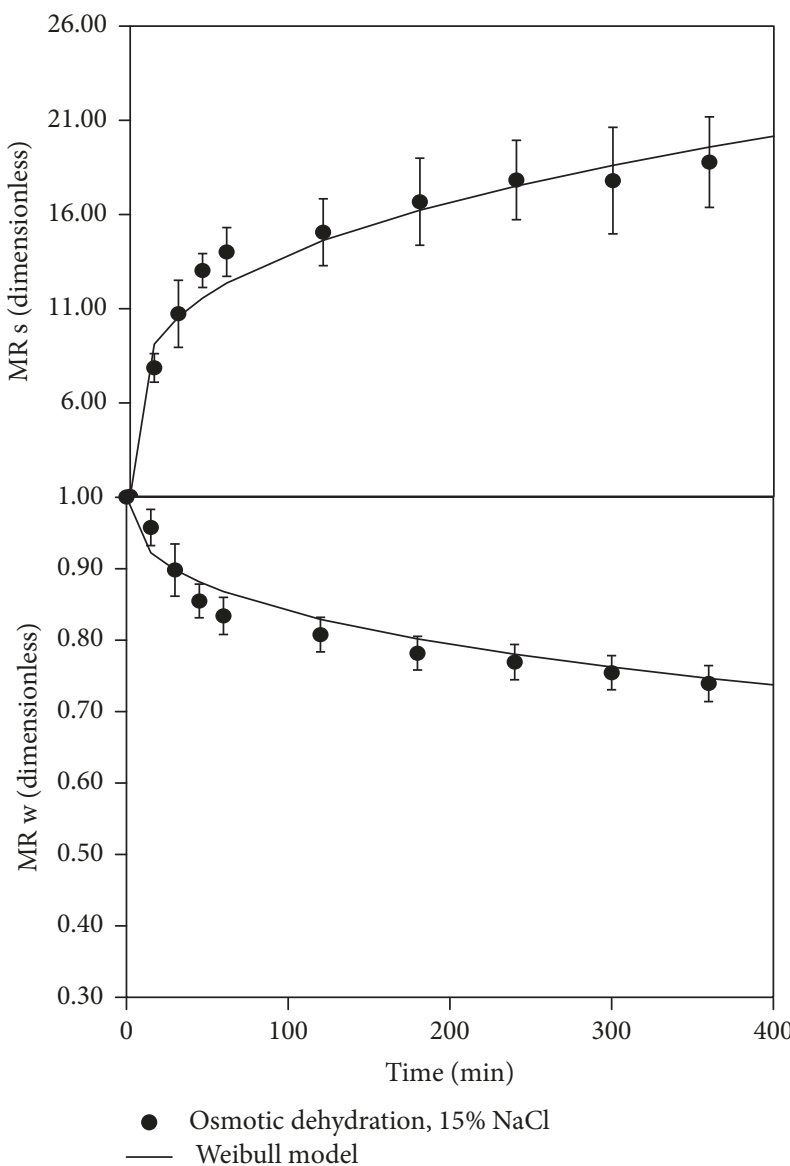

FIGURE 1: Experimental water and salt transfer during osmotic process and calculated by Weibull model.

temperatures. Cunningham et al. [43] explained that the $\beta$ parameter represents the time required for $63 \%$ of the whole drying process, approximately. Furthermore, this parameter was related to the mass transfer ( $\mathrm{min}$ ) at the beginning of the process; therefore, if the $\beta$ value was lower, the transference speed was faster [44], and a reduction of $\alpha$ parameter indicates greater water absorption and desorption of the dehydrated product.

\subsection{Quality Characteristics}

4.4.1. Proximate Analysis and Water Activity $\left(a_{w}\right)$. The proximate composition of osmotically treated samples was 76.6 for the moisture content, 13.3 for the protein content, 1.73 for the

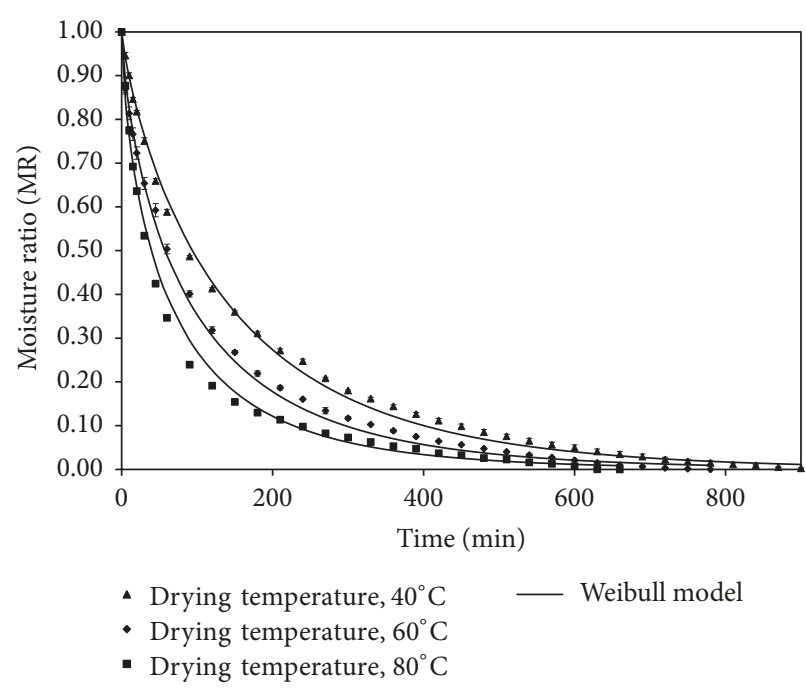

FIGURE 2: Experimental drying curves modeled by the Weibull model.

lipid content, and 5.83 for the carbohydrate content $(\mathrm{g} / 100 \mathrm{~g}$ d.m.); furthermore, the water activity value was 0.97 . While the moisture content values of dried samples ranged between 26.45 and $18.03 \mathrm{~g} / 100 \mathrm{~g}$ d.m., the lipid content varied from 7.26 to 3.16 (g/100 g d.m.), the carbohydrate content varied from 28.24 to $32.58 \mathrm{~g} / 100 \mathrm{~g} \mathrm{~d} . \mathrm{m}$., and at last, the protein content showed values from 55.94 to $35.93 \mathrm{~g}$ d.m, according to the temperatures applied. These values have a similar tendency to the ones reported by other authors who studied drying and brining jumbo squid [45]. The safety limit for $a_{w}$ in the foods is 0.6 [46]. This research yielded values of $0.77 \pm 0.02$ to $0.67 \pm$ 0.04 . Chiou et al. [45] obtained the same trend in cuttlefish drying subjected to a pretreatment salt. From the microbiological point of view, there might be some chemical, biochemical, or metabolic reactions of growth due to the quantity of water that is available. However, owing to the fact that the abalone was subjected to an osmotic pretreatment at $15 \%$ $\mathrm{NaCl}$, it will cause a slower growth of some microorganism because of the difference in the osmotic pressure or because of chloride ions that are deadly for some pathogens [47], affecting the enzymatic systems and consequently the chemical reaction speed will be reduced.

4.4.2. Surface Color and Nonenzymatic Browning (NEB). Color changes are in connection with the changes in the structural protein that bring about a difference in light dispersion properties on the surface of abalone samples, 
TABLE 2: Quality parameters such as TPA, TVBN, and antioxidant activity of fresh and dehydrated samples.

\begin{tabular}{lcccc}
\hline Quality parameters & Fresh & \multicolumn{2}{c}{ Drying temperature $\left({ }^{\circ} \mathrm{C}\right)$} \\
& & 40 & 60 & 80 \\
\hline Texture profile analysis (TPA) & & & & \\
Chewiness (mm) & $2040 \pm 976^{\mathrm{a}}$ & $1308 \pm 527^{\mathrm{a}}$ & $2016 \pm 246^{\mathrm{b}}$ & $3833.25 \pm 1693^{\mathrm{a}}$ \\
Springiness (mm) & $0.68 \pm 0.14^{\mathrm{a}}$ & $0.70 \pm 0.11^{\mathrm{ab}}$ & $0.77 \pm 0.08^{\mathrm{bc}}$ & $0.85 \pm 0.08^{\mathrm{c}}$ \\
Resilience & $0.30 \pm 0.07^{\mathrm{b}}$ & $0.24 \pm 0.03^{\mathrm{a}}$ & $0.31 \pm 0.02^{\mathrm{a}}$ & $0.34 \pm 0.04^{\mathrm{c}}$ \\
Cohesiveness & $0.52 \pm 0.09^{\mathrm{a}}$ & $0.63 \pm 0.05^{\mathrm{a}}$ & $0.70 \pm 0.03^{\mathrm{c}}$ & $0.74 \pm 0.04^{\mathrm{b}}$ \\
Hardness (N/mm) & $21.43 \pm 15.95^{\mathrm{a}}$ & $29.57 \pm 10.24^{\mathrm{ab}}$ & $37.06 \pm 15.16^{\mathrm{b}}$ & $55.22 \pm 18.16^{\mathrm{c}}$ \\
\hline TVBN (mg N/100 mg) & $10.57 \pm 0.03^{\mathrm{a}}$ & $45.24 \pm 0.09^{\mathrm{b}}$ & $47.66 \pm 0.64^{\mathrm{c}}$ & $53.65 \pm 0.34^{\mathrm{d}}$ \\
Antioxidant activity $(\mu \mathrm{mol} \mathrm{TE} / \mathrm{d} . \mathrm{m})$. & $28.82 \pm 0.003^{\mathrm{a}}$ & $8.70 \pm 0.003^{\mathrm{b}}$ & $8.55 \pm 0.273^{\mathrm{b}}$ & $8.08 \pm 0.151^{\mathrm{c}}$ \\
\hline
\end{tabular}

Identical letters above the values indicate no significant difference $(p<0.05)$. Values are mean \pm standard deviation $(n=3)$.

like browning reactions [47]. Figure 3 shows the changes of $L^{*}, a^{*}, b^{*}, \Delta E$, and NEB parameters from fresh and rehydrated samples. According to ANOVA, the luminosity $\left(L^{*}\right)$ attained statistically significant differences in all the treatments, resulting in their decrease, which were observed at $95 \%$ confidence level $(p<0.05)$, among the mean values that resulted in two homogeneous groups $\left(40-60-80^{\circ} \mathrm{C}\right.$ and fresh), which can be explained because the luminosity was affected mainly by $\mathrm{NaCl}$ osmotic pretreatment [47] and the drying temperature $[1,29]$. The yellowness $\left(b^{*}\right)$ increased during the drying temperature due to the browning [48]; that is, it was proved that the temperatures used affected the $b^{*}$ parameter, since these ones showed significant differences $(p<0.05)$ in the average value for each temperature. Similar values were obtained by Ortiz et al. [38] in salmon drying and by Vega-Gálvez et al. [1,29] in jumbo squid osmo-treated drying. This also occurs in $a^{*}$ parameter, where there were significant statistical differences that attained a confidence value of $95 \%(p<0.05)$. As in the case of color variation $(\Delta E)$, it also increased with the drying temperatures [38] from 12.35 to 14.15 . However, the statistical study revealed that no significant differences were found among treatments that had a value $p>0.05$, with a homogeneous group $\left(40-60-80^{\circ} \mathrm{C}\right)$.

Maillard type reactions or nonenzymatic browning (NEB) occurs because carbonyl compounds react with amino-groups when thermal treatments are applied on the muscular tissues that usually contain carbohydrates like glycogen, reducing sugars, and nucleotides [49], which was evidenced by the decrease in the value of $L^{*}$ and increase of $b^{*}$ parameter. The abalone is abundant in proteins and free amino-acids; therefore, it can be observed that temperature increase brought about an important chestnut colored compound formation. This was observed because the NEB compounds increased with the increase in temperature resulting in brown compounds. The NEB treatment at $80^{\circ} \mathrm{C}$ obtained a $0.27 \pm 0.023$ value Abs/g d.m. like Rahman [49] that evaluated other seafood products.

4.5. Texture Profile Analysis (TPA). Seafood muscle tissue is formed by muscle fibers cells located in the interstitial medium and capillary space medium. Muscular cells are mainly fibrils, sarcoplasm, and the connective tissue, specifically collagen [50]. The principal structural factors that affect

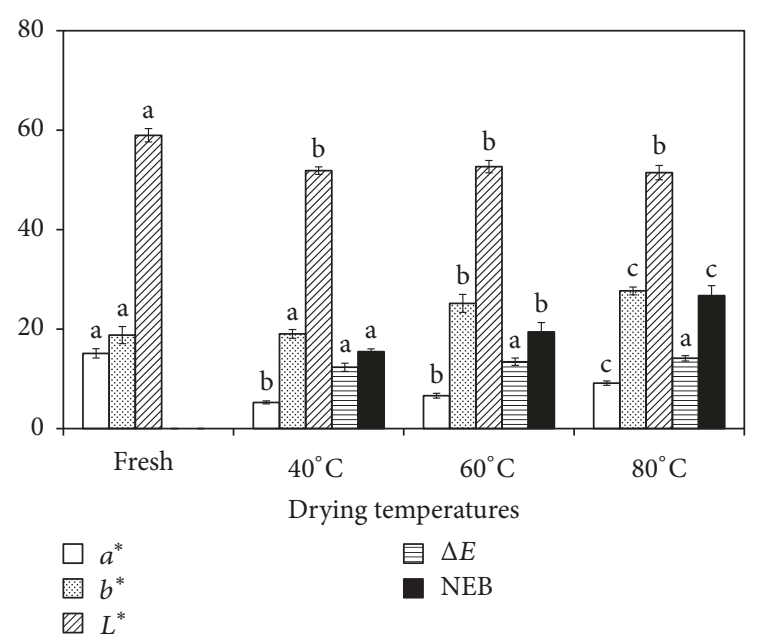

FIGURE 3: Effect of drying temperature on color differences $(\Delta E)$, chromaticity coordinates $L^{*}, a^{*}$, and $b^{*}$ (whiteness or brightness, redness/greenness, and yellowness/blueness), and nonenzymatic browning $\left(\mathrm{NEB} \times 10^{-2}\right)$ of fresh and rehydrated abalone. Different letters above the bars indicate significant differences $(p<0.05)$.

the texture are associated with the connective tissues and myofibrils proteins (actins and myosin) [51]. The myofibrils proteins such as the myosin play an important role in the quality of meat owing to their capacity to hold water [52].

Based on the above, the texture is one of the most important characteristics that affect the quality of the product when it is chewed by the consumer [53]. Table 2 shows the effects of drying temperature on the fresh and rehydrated texture samples. The latter display a significant influence with increasing temperature [29]. Comparable results have been reported in baking squid [53] and during shrimp drying [54]. Drying causes protein denaturation by irreversible structural changes that lead to a change in texture [2]. Dried abalone samples firmness is a critical parameter affecting the quality and hence the acceptability of the product. All treatments prior to drying showed an increase compared to the fresh sample and can be explained by the effect of the drying temperature, the $\mathrm{NaCl}$ concentration on tissue proteins [55]. Firmness values between a fresh abalone and a dried-hydrated one at the highest drying temperature varied 
from 21.43 to $54.12 \mathrm{~N} / \mathrm{mm}$. The same tendency was reported by Vega-Gálvez et al. [29], for the osmo-treated cuttlefish drying and by Ortiz et al. [38], on salmon drying.

4.6. Rehydration Indexes. Most products dehydrated are rehydrated before consumption. Rehydration can be regarded as an indirect measure of tissue damage caused by drying [29]. Figure 4 shows the rehydration ratio (RR) together with the water holding capacity (WHC) for different treatments used. This figure indicated that treatment at $60^{\circ} \mathrm{C}$ obtained $\mathrm{RR}$ increased compared to the other treatments $(1.26 \mathrm{~g}$ absorbed water/g dry matter). The treatment at $40^{\circ} \mathrm{C}$ reveals slightly lower value as compared to 60 to $80^{\circ} \mathrm{C}$. Moreover, it is generally accepted that the degree of rehydration depends on the degree of cell structural alteration [47], because if the drying temperature increases, the higher the rehydration capacity will be, due to its lower water retention capacity that was caused by structural damage at the cellular level, resulting, among other effects, in leaching of soluble solids [56].

WHC value shows a tendency to decrease as the treatment temperature increases; thus, at $40^{\circ} \mathrm{C}$ the treatment has the highest water holding capacity $(98.96 \mathrm{~g}$ retained water $/ 100 \mathrm{~g}$ water) and the lowest at $80^{\circ} \mathrm{C}(95.25 \mathrm{~g}$ retained water $/ 100 \mathrm{~g}$ water). Similar results were reported by other authors who described that drying temperature was the main factor of WHC decrease, becoming an obstacle to retain this water. In particular, Vega-Gálvez et al. [29] working in cuttlefish found similar results. Besides, it must be pointed out that abalone and all the meat species have a good water holding capacity, due to their protein feature of a myofibril origin [52].

4.7. Antioxidant Capacity. The results in Table 2 show that the antioxidant capacity obtained a decrease with the process temperatures; that is, it can be observed that the variable temperature has a significant effect on the antioxidant activity of the abalone samples. These results also were reported by Bennett et al. [57] concluding that the drying and processing conditions affect the antioxidant capacity of foods. All the treatments showed a diminishing of such an activity as compared to a fresh sample that obtained $28.824 \mu \mathrm{mol} \mathrm{TE} / \mathrm{g}$ d.m. A similar behavior was also observed at $60^{\circ} \mathrm{C}$ and $80^{\circ} \mathrm{C}$ due to the same period under thermal process. This can be explained by the osmotic pretreatment that the abalone has, which might produce $\mathrm{NaCl}$ crystals, as a barrier to the water outlet (Collignan et al., 2000), affecting the drying process. The antioxidant activity of seafood has been related to proteins and has been reported of different peptides having antioxidant effects [58]. However, the relationship between antioxidant activity and content of active peptide has not been fully studied yet in the process [58].

4.8. Total Volatile Basic Nitrogen (TVBN). TVBN values that are reported in this research are in a range from 10.57 to $53.65 \mathrm{mg} \mathrm{N} / 100 \mathrm{~g}$ from samples fresh and dehydrated, which can be better valued from Table 2 . These values vary according to the fishtailed species, the environment, physiological conditions, processing, and storage conditions [48].

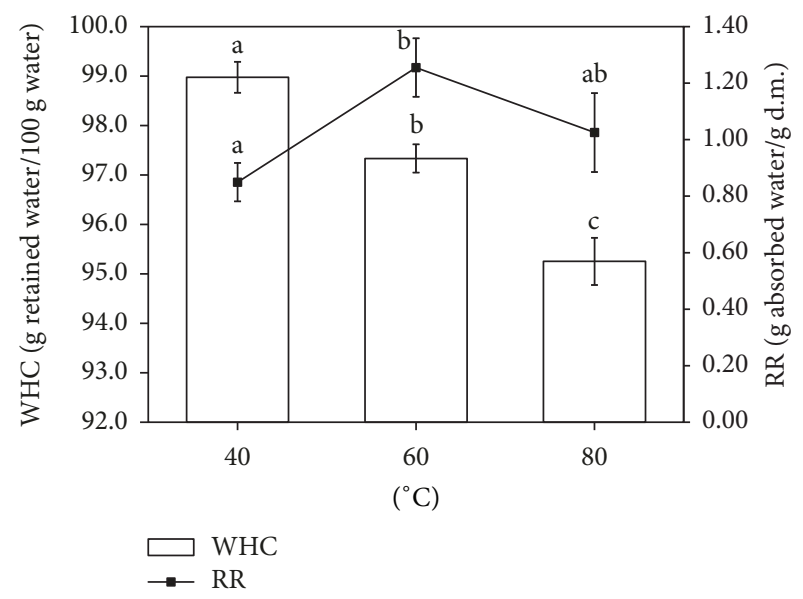

FIGURE 4: Effect of air-drying temperature on the rehydration ratio (RR) and the water holding capacity (WHC) for dry-rehydrated abalone samples. Identical letters above the bars indicate no significant difference $(p<0.05)$.

Table 2 shows an increase in the amount of TVBN as the temperature increases, due to the low molecular weight volatile compounds that increase the amount of nitrogen considerably with the heat treatment [29]. Similar results were found by Robles et al. [59] when applying thermal treatments on crabs (Homalaspis plana). The total basic volatile nitrogen content (TVBN) has been worldwide used as an indicator of fish quality [60]. The fresh value was $10.57 \pm 0.03 \mathrm{mg} \mathrm{N} / 100 \mathrm{~g}$, sample that can be compared to fresh seafood reported by other authors [59].

TVBN content increases by the thermal treatment due to the longer heat exposition, according to Gallardo et al. $[61,62]$. During thermal treatment, the composition and proportion of the nitrogenous compounds cause changes in the amine's molecular weight contents; that is, TVBN increases as a consequence of some amino-acids degradation [59]. TVBN values of meat subjected to a thermal treatment are always higher than fresh meat [61]. Studies carried out in canned mussels and squids and other fish species that underwent some thermal treatment showed TVBN values of 42.5$57.3 \mathrm{mg} / 100 \mathrm{~g}$ of muscles [62]. According to ANOVA $(p<$ $0.05)$, there was a significant difference between the average values of the total content of volatile nitrogen for treatments studied.

\section{Conclusion}

This study has shown that the concentration of the osmotic treatment influences directly the diffusional coefficient of water and salt in the process, obtaining a balance between $270<\min <300$. These values ranged from 2.74 to $7.19 \times$ $10^{-10} \mathrm{~m}^{2} / \mathrm{s}$, respectively. As for the effective diffusivity of water in the drying process, there was a tendency to increase regarding the evaluated temperatures, whose values oscillated from 3.76 to $4.76 \times 10^{-9} \mathrm{~m}^{2} / \mathrm{s}$. The Weibull model obtained a good fit in the OD and drying, corroborating with statistical test $0.0006<\chi^{2}<1.09,0.0005<\operatorname{SSE}<0.8934$, and $0.91<r^{2}<$ 0.94 . The drying temperature significantly influenced the 
physical, chemical, and nutritional properties of abalone samples. Discoloration of product was more evident at high drying temperatures, where combined effects of nonenzymatic browning as well as protein denaturation modified the abalone samples original color. According to the drying temperature, the RR and WHC indexes showed a decrease, while the texture presented an increase. TVBN and antioxidant activity values presented a decrease with increased temperature. Therefore, the results of this work indicate that the drying kinetics along with quality aspects of dried abalones can be used to improve the final characteristics of the product and predict a suitable drying treatment at $60^{\circ} \mathrm{C}$ under an osmotic pretreatment $(15 \% \mathrm{NaCl})$.

\section{Nomenclature}

OD: Osmotic dehydration

$D_{e}: \quad$ Mass effective diffusivity $\left(\mathrm{m}^{2} / \mathrm{s}\right)$

$S_{t}: \quad$ Salt content (g NaCl/g dry matter, d.m.)

$M_{t}$ : Water content (g water/g d.m.)

SR: $\quad$ Salt ratio (dimensionless)

MR: Moisture ratio (dimensionless)

$L$ : $\quad$ Sample thickness (m)

$E_{a}: \quad$ Activation energy $(\mathrm{kJ} / \mathrm{mol})$

$L^{*}$ : Whiteness/darkness color parameter

$a^{*}$ : $\quad$ Redness/greenness color parameter

$b^{*}$ : Yellowness/blueness color parameter

RH: $\quad$ Relative humidity (\%)

RR: Rehydration ratio (g absorbed water/g dry matter)

WHC: Water holding capacity (g retained water/100 g water)

TE: $\quad \mu \mathrm{mol}$ of trolox equivalents

$R: \quad$ Universal gas constant $(8.314 \mathrm{~J} / \mathrm{mol} \mathrm{K})$

$D_{o}: \quad$ Arrhenius factor $\left(\mathrm{m}^{2} / \mathrm{s}\right)$

T: $\quad$ Temperature $\left({ }^{\circ} \mathrm{C}\right.$ or $\left.\mathrm{K}\right)$

$W: \quad$ Weight of the sample (g)

$t$ : $\quad$ Time (min)

$N$ : Number of data.

\section{Greek Letters}

$\alpha$ : Shape parameter of Weibull model (dimensionless) $\beta$ : Scale parameter of Weibull model (min).
Subscripts
$w$ : Water
$s$ : Salt
$t$ : At time
$o$ : Initial
$r$ : Rehydrated sample
$d$ : Dried sample
$l$ : Drained liquid after centrifugation
$i$ : Number of terms
$c$ : Calculated
e: Experimental.

\section{Conflicts of Interest}

The authors declare that there are no conflicts of interest regarding the publication of this paper as well as the received funding.

\section{Acknowledgments}

The authors gratefully acknowledge the financial support provided by Concurso DIULS Apoyo Tesis de Postgrado Project no. PT14332 and FONDECYT Regular Project no. 1140067.

\section{References}

[1] A. Vega-Gálvez, R. Lemus-Mondaca, D. Plaza-Sáez, and M. Pérez-Won, "Effect of air-temperature and diet composition on the drying process of pellets for japanese abalone (haliotis discus hannai) feeding," Ciência e Tecnologia de Alimentos, vol. 31, no. 3, pp. 694-702, 2011.

[2] B. Zhu, X. Dong, L. Sun et al., "Effect of thermal treatment on the texture and microstructure of abalone muscle (Haliotis discus)," Food Science and Biotechnology, vol. 20, no. 6, pp. 14671473, 2011.

[3] Sernapesca. 2015. Servicio nacional de Pesca de Chile. Leyes y Reglamentos; Normativas y Valparaíso: Ministerio de Economia, Fomento y Turismo. Disponible en: http://www.sernapesca .cl;. Acesso em: Jun 10, 2015.

[4] T. Tsironi, I. Salapa, and P. Taoukis, "Shelf life modelling of osmotically treated chilled gilthead seabream fillets," Innovative Food Science and Emerging Technologies, vol. 10, no. 1, pp. 23-31, 2009.

[5] A. Z. Valencia-Pérez, M. H. García-Morales, J. L. CárdenasLópez, J. R. Herrera-Urbina, O. Rouzaud-Sández, and J. M. Ezquerra-Brauer, "Effect of thermal process on connective tissue from jumbo squid (Dosidicus gigas) mantle," Food Chemistry, vol. 107, no. 4, pp. 1371-1378, 2008.

[6] B. S. M. Mahmoud, K. Yamazaki, K. Miyashita, Y. Kawai, I.-S. Shin, and T. Suzuki, "Preservative effect of combined treatment with electrolyzed $\mathrm{NaCl}$ solutions and essential oil compounds on carp fillets during convectional air-drying," International Journal of Food Microbiology, vol. 106, no. 3, pp. 331-337, 2006.

[7] A. Vega-Gálvez, K. Di Scala, K. Rodríguez et al., "Effect of airdrying temperature on physico-chemical properties, antioxidant capacity, colour and total phenolic content of red pepper (Capsicum annuum, L. var. Hungarian)," Food Chemistry, vol. 117, no. 4, pp. 647-653, 2009.

[8] S. Bellagha, A. Sahli, A. Farhat, N. Kechaou, and A. Glenza, "Studies on salting and drying of sardine (Sardinella aurita): Experimental kinetics and modeling," Journal of Food Engineering, vol. 78, no. 3, pp. 947-952, 2007.

[9] E. K. Akpinar, "Determination of suitable thin layer drying curve model for some vegetables and fruits," Journal of Food Engineering, vol. 73, no. 1, pp. 75-84, 2006.

[10] K. Di Scala and G. Crapiste, "Drying kinetics and quality changes during drying of red pepper," LWT- Food Science and Technology, vol. 41, no. 5, pp. 789-795, 2008.

[11] N. E. Perez and M. E. Schmalko, "Convective drying of pumpkin: Influence of pretreatment and drying temperature," Journal of Food Process Engineering, vol. 32, no. 1, pp. 88-103, 2009. 
[12] R. Lemus-Mondaca, M. Miranda, A. Andres Grau, V. Briones, R. Villalobos, and A. Vega-Gálvez, "Effect of osmotic pretreatment on hot air drying kinetics and quality of Chilean papaya (Carica pubescens)," Drying Technology, vol. 27, no. 10, pp. 11051115, 2009.

[13] R. Lemus-Mondaca, S. Noma, N. Igura, M. Shimoda, and M. Pérez-Won, "Kinetic Modeling and Mass Diffusivities during Osmotic Treatment of Red Abalone (Haliotis rufescens) Slices," Journal of Food Processing and Preservation, vol. 39, no. 6, pp. 1889-1897, 2015.

[14] I. Doymaz, "Drying of leek slices using heated air," Journal of Food Process Engineering, vol. 31, no. 5, pp. 721-737, 2008.

[15] L. Ait Mohamed, C. S. Ethmane Kane, M. Kouhila, A. Jamali, M. Mahrouz, and N. Kechaou, "Thin layer modelling of Gelidium sesquipedale solar drying process," Energy Conversion and Management, vol. 49, no. 5, pp. 940-946, 2008.

[16] O. Corzo and N. Bracho, "Application of Weibull distribution model to describe the vacuum pulse osmotic dehydration of sardine sheets," LWT-Food Science and Technology, vol. 41, no. 6, pp. 1108-1115, 2008.

[17] V. Heinz and D. Knorr, "High pressure inactivation kinetics of Bacillus subtilis cells by a three-state-model considering distributed resistance mechanisms," Food Biotechnology, vol. 10, no. 2, pp. 149-161, 1996.

[18] M. F. Machado, F. A. R. Oliveira, and L. M. Cunha, "Effect of milk fat and total solids concentration on the kinetics of moisture uptake by ready-to-eat breakfast cereal," Int J Food Sci Tech.34, pp. 47-57, 1999.

[19] L. M. Cunha, F. A. R. Oliveira, A. P. Aboim, and J. M. Frías, "a.Stochastic approach to the modelling of water losses during osmotic dehydration and improved parameter estimation," in Proceedings of the a.Stochastic approach to the modelling of water losses during osmotic dehydration and improved parameter estimation. International J Food Sci Tech. 36: 253-262, vol. 36, pp. 253-262, 2001.

[20] A. Fernández, J. Collado, L. M. Cunha, M. J. Ocio, and A. Martinez, "Empirical model building based on Weibull distribution to describe the joint effect of $\mathrm{pH}$ and temperature on the termal resistance of Bacillus cereus in vegetable substrate," Int J Food Micr, pp. 77-147, 2002.

[21] N. Boudhrioua, N. Djendoubi, S. Bellagha, and N. Kechaou, "Study of moisture and salt transfers during salting of sardine fillets," Journal of Food Engineering, vol. 94, no. 1, pp. 83-89, 2009.

[22] J. M. Barat, L. Gallart-Jornet, A. Andrés, L. Akse, M. Carlehög, and O. T. Skjerdal, "Influence of cod freshness on the salting, drying and desalting stages," Journal of Food Engineering, vol. 73, no. 1, pp. 9-19, 2006.

[23] Y. Wang, M. Zhang, and A. S. Mujumdar, "Convective drying kinetics and physical properties of silver carp (Hypophthalmichthys molitrix) fillets," Journal of Aquatic Food Product Technology, vol. 20, no. 4, pp. 361-378, 2011.

[24] J. Crank, The Mathematics of Diffusion, Clarendon Press, Oxford, UK, 2nd edition, 1975.

[25] E. Uribe, M. Miranda, A. Vega-Gálvez, I. Quispe, R. Clavería, and K. Di Scala, "Mass Transfer Modelling During Osmotic Dehydration of Jumbo Squid (Dosidicus gigas): Influence of Temperature on Diffusion Coefficients and Kinetic Parameters," Food and Bioprocess Technology, vol. 4, no. 2, pp. 320-326, 2011.

[26] S. Simal, A. Femenia, M. C. Garau, and C. Rosselló, "Use of exponential, Page's and diffusional models to simulate the drying kinetics of kiwi fruit," Journal of Food Engineering, vol. 66, no. 3, pp. 323-328, 2005.

[27] O. Corzo and N. Bracho, "Application of Normalized Weibull Model in the Osmotic Dehydration of Sardine Sheets," Revista Cientifica, vol. XIX, no. 4, pp. 400-407, 2009.

[28] S. Buzrul, H. Alpas, and F. Bozoglu, "Use of Weibull frequency distribution model to describe the inactivation of Alicyclobacillus acidoterrestris by high pressure at different temperatures," Food Research International, vol. 38, no. 2, pp. 151-157, 2005.

[29] A. Vega-Gálvez, M. Miranda, R. Clavería et al., "Effect of air temperature on drying kinetics and quality characteristics of osmo-treated jumbo squid (Dosidicus gigas)," LWT- Food Science and Technology, vol. 44, no. 1, pp. 16-23, 2011.

[30] J. R. BOTTA, J. T. LAUDER, and M. A. JEWER, "Effect of Methodology on Total Volatile Basic Nitrogen (TVB-N) Determination as an Index of Quality of Fresh Atlantic Cod (Gadus morhua)," Journal of Food Science, vol. 49, no. 3, pp. 734-736, 1984.

[31] W. Brand-Williams, M. E. Cuvelier, and C. Berset, "Use of a free radical method to evaluate antioxidant activity," $L W T$ - Food Science and Technology, vol. 28, no. 1, pp. 25-30, 1995.

[32] P. Molyneux, "The use of the stable radical Diphenylpicrylhydrazyl (DPPH) for estimating antioxidant activity", Songklanakarin Journal of Science and Technology, vol. 26, no. 2, pp. 211-219, 2004.

[33] Y. Wang, J. Yue, Z. Liu et al., "Impact of Far-Infrared Radiation Assisted Heat Pump Drying on Moisture Distribution and Rehydration Kinetics of Squid Fillets During Rehydration," Journal of Aquatic Food Product Technology, vol. 25, no. 2, pp. 147-155, 2016.

[34] V. R. N. Telis, P. F. Romanelli, A. L. Gabas, and J. Telis-Romero, "Salting kinetics and salt diffusivities in farmed Pantanal caiman muscle," Pesquisa Agropecuária Brasileira, vol. 38, no. 4, pp. 529535, 2003.

[35] S. Mujaffar and C. K. Sankat, "The mathematical modelling of the osmotic dehydration of shark fillets at different brine temperatures," International Journal of Food Science \& Technology, vol. 41, no. 4, pp. 405-416, 2006.

[36] M. F. Villacís, N. K. Rastogi, and V. M. Balasubramaniam, "Effect of high pressure on moisture and $\mathrm{NaCl}$ diffusion into turkey breast," LWT- Food Science and Technology, vol. 41, no. 5, pp. 836-844, 2008.

[37] N. M. Panagiotou, M. K. Krokida, Z. B. Maroulis, and G. D. Saravacos, "Moisture diffusivity: Literature data compilation for foodstuffs," International Journal of Food Properties, vol. 7, no. 2, pp. 273-299, 2004.

[38] J. Ortiz, R. Lemus-Mondaca, A. Vega-Gálvez et al., "Influence of air-drying temperature on drying kinetics, colour, firmness and biochemical characteristics of Atlantic salmon (Salmo salar L.) fillets," Food Chemistry, vol. 139, no. 1-4, pp. 162-169, 2013.

[39] M. Medina-Vivanco, P. J. A. Do Sobral, and M. D. Hubinger, "Osmotic dehydration of tilapia fillets in limited volume of ternary solutions," Chemical Engineering Journal, vol. 86, no. 1-2, pp. 199-205, 2002.

[40] I. Doymaz, "Drying characteristics and kinetics of okra," Journal of Food Engineering, vol. 69, no. 3, pp. 275-279, 2005.

[41] P. Fito, A. M. Andrés, J. M. Barat, A. M. Albors, and A. M. Andrés, Introducción al Secado de Alimentos por Aire Caliente, Editorial U.P.V, Valencia, España, 2001.

[42] A. Vega, P. Fito, A. Andrés, and R. Lemus, "Mathematical modeling of hot-air drying kinetics of red bell pepper (var. 
Lamuyo)," Journal of Food Engineering, vol. 79, no. 4, pp. 14601466, 2007.

[43] S. E. Cunningham, W. A. M. McMinn, T. R. A. Magee, and P. S. Richardson, "Modelling water absorption of pasta during soaking," Journal of Food Engineering, vol. 82, no. 4, pp. 600607, 2007.

[44] M. F. Machado, F. A. R. Oliveira, V. Gekas, and R. P. Singh, "Kinetics of moisture uptake and soluble-solids loss by puffed breakfast cereals immersed in water," International Journal of Food Science \& Technology, vol. 33, no. 3, pp. 225-237, 1998.

[45] T. Chiou, H. Chang, L. Lo, H. Lan, and C. Shiau, "Changes in chemical constituents and physical índices during processing of dried-seasoned squid," Fish Sci, pp. 66-708, 2000.

[46] A. Vega-Gálvez, M. Palacios, F. Boglio, C. Pássaro, C. Jeréz, and R. Lemus-Mondaca, "Deshidratación osmótica de la papaya chilena (Vasconcellea pubescens) e influencia de la temperatura y concentración de la solución sobre la cinética de transferencia de materia," Ciência e Tecnologia de Alimentos, vol. 27, no. 3, pp. 470-477, 2007.

[47] N. Guizani, A. O. Al-Shoukri, A. Mothershaw, and M. S. Rahman, "Effects of salting and drying on shark (Carcharhinus sorrah) meat quality characteristics," Drying Technology, vol. 26, no. 6, pp. 705-713, 2008.

[48] S.-C. Shen, K.-C. Tseng, and J. S.-B. Wu, "An analysis of Maillard reaction products in ethanolic glucose-glycine solution," Food Chemistry, vol. 102, no. 1, pp. 281-287, 2007.

[49] S. Rahman, "Drying of fish and seafood," in Handbook of industrial drying, A. S and Mujumdar., Eds., CRC Press, Boca Raton, FL, USA, 3 edition, 2006.

[50] S. K. Øiseth, C. Delahunty, M. Cochet, and L. Lundin, "Why is abalone so chewy? structural characterization and relationship to textural attributes," Journal of Shellfish Research, vol. 32, no. 1, pp. 73-79, 2013.

[51] F. Erdogdu and M. Balaban, "Thermal processing effects on the textural attributes of previously frozen shrimp," J Aquat Food Prod Tech, pp. 67-84, 2000.

[52] N. Chapleau, C. Mangavel, J.-P. Compoint, and M. De Lamballerie-Anton, "Effect of high-pressure processing on myofibrillar protein structure," Journal of the Science of Food and Agriculture, vol. 84, no. 1, pp. 66-74, 2004.

[53] W. S. Otwell and D. D. Hamann, "Textural characterizati, on of squid (loligo pealei 1.): instrumental and panel evaluations," Journal of Food Science, vol. 44, no. 6, pp. 1636-1643, 1979.

[54] Y. Namsanguan, W. Tia, S. Devahastin, and S. Soponronnarit, "Drying kinetics and quality of shrimp undergoing different two-stage drying processes," Drying Technology, vol. 22, no. 4, pp. 759-778, 2004.

[55] L. Gallart-Jornet, J. M. Barat, T. Rustad, U. Erikson, I. Escriche, and P. Fito, "Influence of brine concentration on Atlantic salmon fillet salting," Journal of Food Engineering, vol. 80, no. 1, pp. 267-275, 2007.

[56] P. García-Pascual, N. Sanjuán, R. Melis, and A. Mulet, "Morchella esculenta (morel) rehydration process modelling," Journal of Food Engineering, vol. 72, no. 4, pp. 346-353, 2006.

[57] L. E. Bennett, H. Jegasothy, I. Konczak, D. Frank, S. Sudharmarajan, and P. R. Clingeleffer, "Total polyphenolics and antioxidant properties of selected dried fruits and relationships to drying conditions," Journal of Functional Foods, vol. 3, no. 2, pp. 115-124, 2011.

[58] S. Jongberg, C. U. Carlsen, and L. H. Skibsted, "Peptides as antioxidants and carbonyl quenchers in biological model systems," Free Radical Research, vol. 43, no. 10, pp. 932-942, 2009.
[59] V. Robles, L. Abugoch, J. Vinagre et al., "Efecto de tratamientos térmicos sobre las características químicas de carne de jaiba mora," Homalaspis plana, vol. 53, pp. 191-223, 2003.

[60] L. Pivarnik, P. Ellis, X. Wang, and T. Reilly, "Standardization of the ammonia electrode method for evaluating seafood quality by correlation to sensory analysis," Journal of Food Science, vol. 66, no. 7, pp. 945-952, 2001.

[61] J. M. Gallardo, R. I. Perez-Martin, J. M. Franco, S. Aubourg, and C. G. Sotelo, "Changes in volatile bases and trimethylamine oxide during the canning of albacore (Thunnus alalunga)," International Journal of Food Science \& Technology, vol. 25, no. 1, pp. 78-81, 1990.

[62] J. M. Gallardo, R. Perez-Martin, J. M. Franco, and S. Aubourg, "Chemical composition and evolution of nitrogen compounds during the processing and storage of canned albacore (Thunnus alalunga," in Proc. M.O.C.C.A, pp. 51-58, Chemical composition and evolution of nitrogen compounds during the processing and storage of canned albacore (Thunnus alalunga). Proc. M.O.C.C.A. 1, 51-58, 1984. 


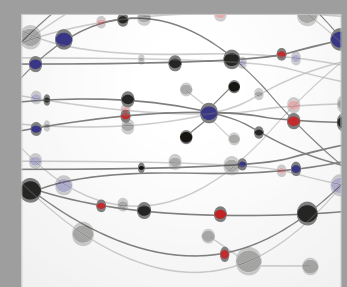

The Scientific World Journal
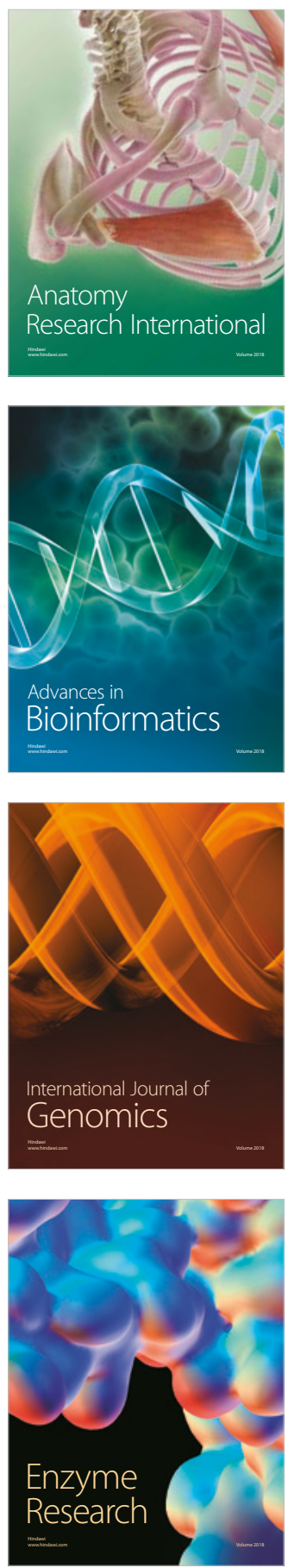
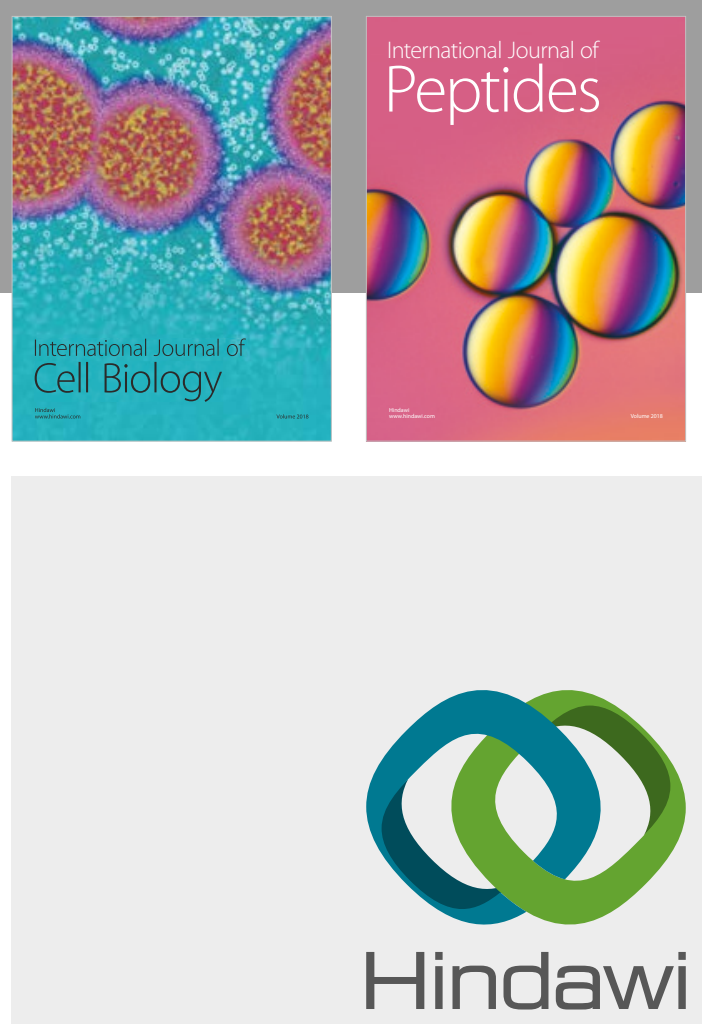

Submit your manuscripts at

www.hindawi.com
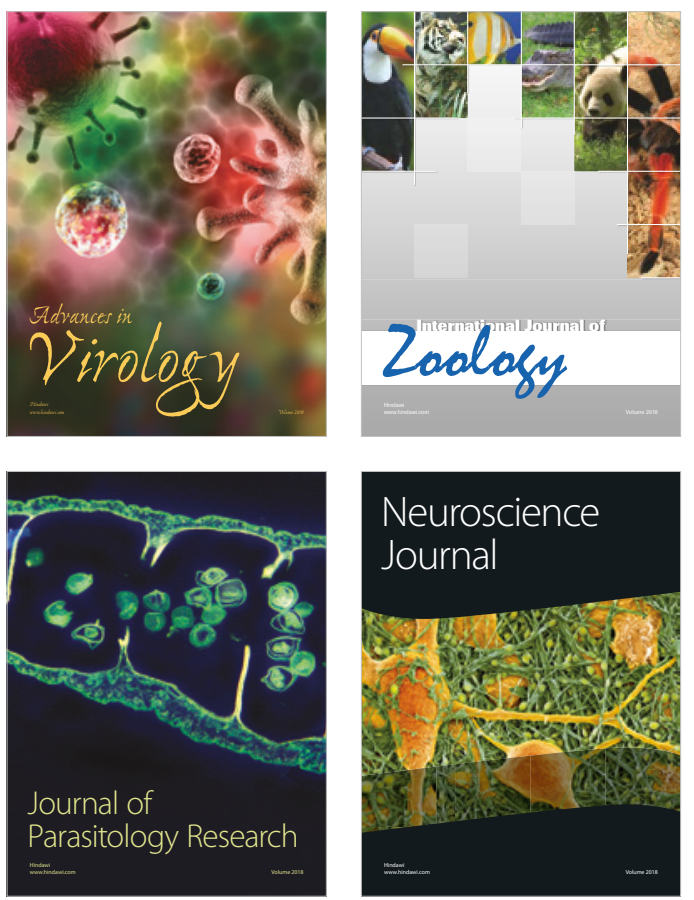
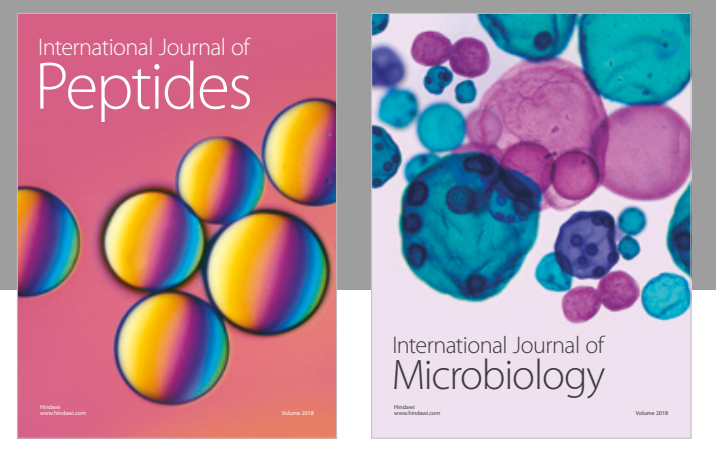

nternational Journal of Microbiology
Journal of
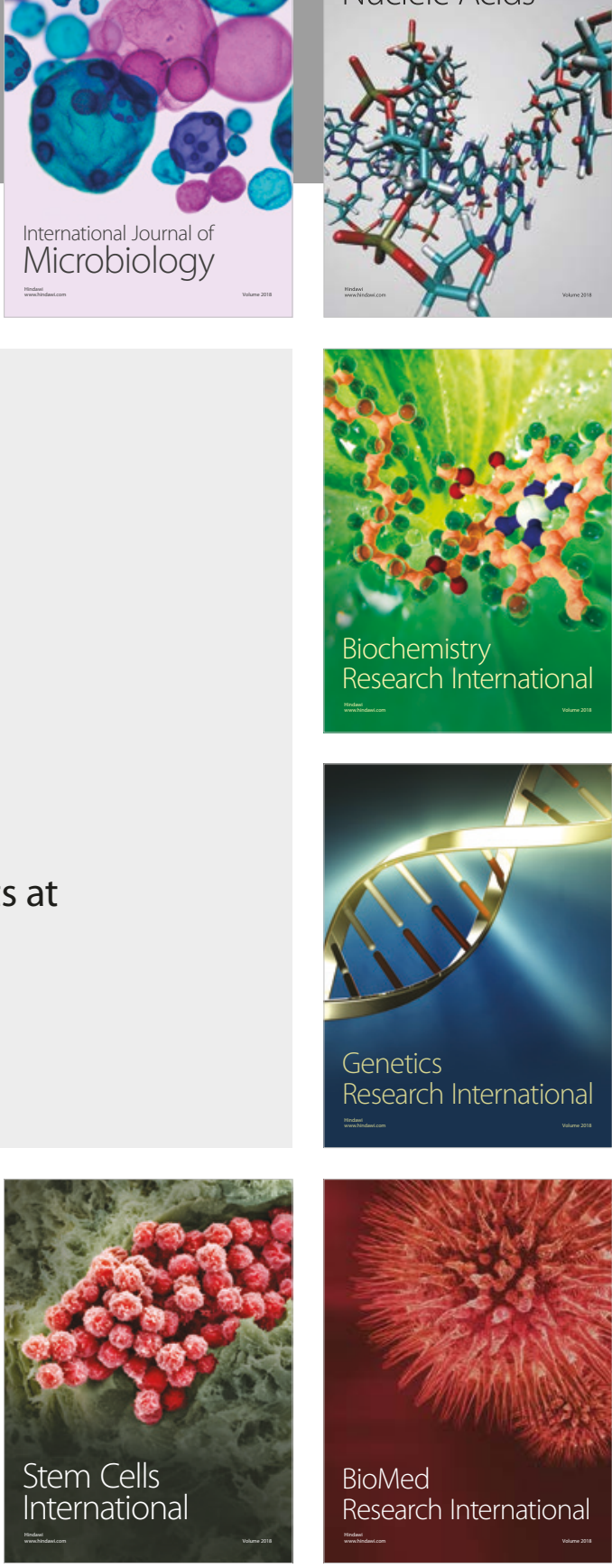
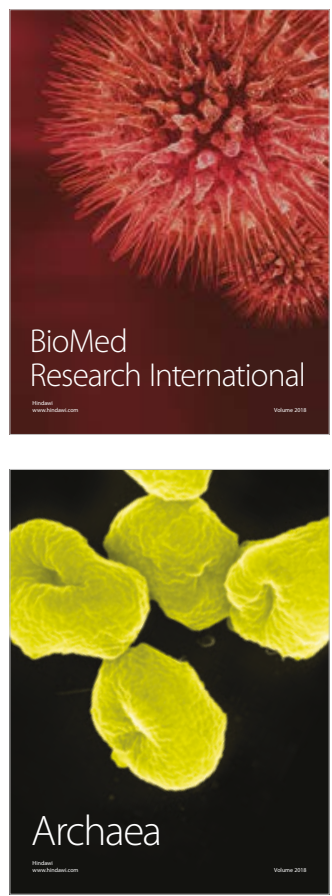